231. LR

DRAFT

Published in Frank Cranmer, et al, eds., The Confluence of Law and Religion:

Interdisciplinary Reflections on the Work of Norman Doe (Cambridge: Cambridge

University Press, 2016), 247-261

\title{
The Interdisciplinary Growth of Law and Religion
}

\author{
John Witte, Jr..
}

\begin{abstract}
Welsh jurist and Anglican theologian Norman Doe has pioneered the modern study of comparative "Christian law" - analyzing the wide variety of internal religious legal systems governing Catholic, Orthodox, and Protestant churches worldwide. For him, law is a fundamental but underutilized instrument of Christian identity, denominationalism, and ecumenism, and he shows the many areas of overlap and collaboration even within and between Christian traditions that have sharp differences on other matters. This Article offers an appreciative analysis of the development of Professor Doe's scholarship, and situates his work within the broader global field of law and religion studies.
\end{abstract}

Keywords: Norman Doe; Church of Wales; Church of England; Roman Catholic Church; Protestantism; Evangelical Churches; canon law; church law; covenant; communion; law and religion.

\section{Introduction}

Over the past two generations, a new interdisciplinary movement has emerged dedicated to the study of the religious dimensions of law, the legal dimensions of religion, and the interaction of legal and religious ideas and institutions, norms and practices. This study is predicated on the assumptions that religion gives law its spirit and inspires its adherence to ritual and justice. Law gives religion its structure and encourages its devotion to order and organization. Law and religion share such ideas as fault, obligation, and covenant and such methods as ethics, rhetoric, and textual interpretation. Law and religion also balance each other by counterpoising justice and mercy, rule and equity, discipline and love. This dialectical interaction gives these two disciplines and dimensions of life their vitality and their strength. 
To be sure, most scholars acknowledge, the spheres and sciences of law and religion have, on occasion, both converged and contradicted each other. Every major religious tradition has known both theonomism and antinomianism -- the excessive legalization and the excessive spiritualization of religion. Every major legal tradition has known both theocracy and totalitarianism -- the excessive sacralization and the excessive secularization of law. But the dominant reality in most eras and most cultures, many scholars now argue, is that law and religion relate dialectically. Every major religious tradition strives to come to terms with law by striking a balance between the rational and the mystical, the prophetic and the priestly, the structural and the spiritual. Every major legal tradition struggles to link its formal structures and processes with the beliefs and ideals of its people. Law and religion are distinct spheres and sciences of human life, but they exist in dialectical interaction, constantly crossing-over and cross-fertilizing each other. 1

\section{The Main Themes of Norman Doe's Scholarship}

Cardiff law professor and Anglican theologian Norman Doe has been an outstanding leader in this emerging field of interdisciplinary study. The Centre for Law and Religion that he founded and directs at Cardiff University is the leading such academic institution in Europe, with an impressive record of pedagogy, projects, and publications, particularly on issues of comparative canon law. He has long been one of the leaders of the European Consortium of Church-State Relations, ${ }^{2}$ and its successor, The International Consortium of Law and Religion Scholars, with several hundred members worldwide. For the past quarter century, he has issued a steady flow of monographs, anthologies, and articles that have helped to map and expand this field. His writings are at once mines of information and fonts of inspiration - prodigiously researched, thickly documented, lucidly argued, relentlessly systematic, exquisitely wrought, but always moderate and measured in tone. To read Norman Doe is to stand on a solid granite rock of scholarship and to gain a new view of the world.

His first major monograph, Fundamental Authority in Late Medieval English Law (1990) 3 put him squarely in the middle of sophisticated medieval discussions of law and religion among theologians, philosophers, moralists, and canonists. Already here, he grappled with some of the fundamental dialectics of this interdisciplinary field -- natural law and positivism, statute and equity, conscience and custom, crime and punishment, authority and liberty, rights and wrongs, theocracy and democracy, church and state,

1 See detailed sources in John Witte, Jr., "The Study of Law and Religion in the United States: An Interim Report," Ecclesiastical Law Journal 14 (2012): 327-354; I have drawn on this text in the opening and closing parts of this chapter.

2 See, e.g., Norman Doe and Russell Sandberg, eds., Law and Religion: New Horizons (Leuven: Peeters, 2010); Richard Puza and Norman Doe, eds., Religion and Law in Dialogue: Covenantal and Non-Covenantal Cooperation Between Religion and State in Europe (Leuven: Peeters, 2006); Norman Doe, The Portrayal of Religion in Europe: The Media and the Arts (Leuven: Peeters, 2004); Norman Doe and Matti Kotiranta, eds., Religion and Criminal Law (Leuven: Peeters, 2013).

3 (Cambridge University Press, 1990). 
canon law and civil law, and more. Already here, he showed his trademark patience with texts - squeezing out of Yearbook cases and obscure sages like Reginald Pecock remarkably prescient and provocative ideas about law and religion.

Since that early book, Professor Doe's most enduring contributions have come in the area of comparative church law, a topic he has mastered in a way that no other modern scholar has done. His work on church law has proceeded in layers, each layer building logically and methodologically on the one before. His first focus in 1992 was on the law of his own Church of Wales, 4 a topic to which he turned several times thereafter, 5 each time with keen insights into how the Welsh model of church and state separation produced a distinct church law system, derivative of and still dependent in part on English ecclesiastical law, but also increasingly self-generated and selfsustaining.

This early study was a prelude to his massive 1996 and 1998 monographs on the law of the Anglican Communion worldwide, an ancient and intricate legal system that, through colonization and missionary work over the centuries, has become transnational, multi-cultural, and multi-lingual in its reach. 6 Here Professor Doe laid out in exquisite detail the latticework of executive, legislative, and judicial forms and functions of the Anglican Church and its bishops, deacons and parish priests; the rules and regulations governing the polity, property, and finances of the local, national, and global church as well as the sundry laws and procedures governing doctrine, liturgy, worship, mission, baptism, catechesis, education, confirmation, confession, marriage, divorce, and more. Part of this lengthy effort was to take the full measure of this complex legal system, with its many centuries-old laws that not only "command" and "prohibit" conduct but also "facilitate," and "encourage" the behavior that is becoming of Anglican clergy and laity in whatever place or circumstance. 7 Part of the effort was to impress on religious and political authorities how important a well-functioning church law system is for the protection of corporate religious freedom and autonomy, and harmonious church-state relationships. And part of this effort was to map the areas in need of reform and adjustment as the global Anglican churches faced various state systems of hard and soft religious establishment and separation, and various forms and forums of accommodation and cooperation with political authorities. 8 No other book, besides

4 Norman Doe, ed., Essays in Canon Law: A Study of the Law of the Church in Wales (Cardiff: University of Wales Press, 1992);

5 See esp. Norman Doe, The Law of the Church of Wales (Cardiff: University of Wales Press, 2002).

6 Norman Doe, Canon Law in the Anglican Communion: A Worldwide Perspective (Oxford: Clarendon Press, 1998); Norman Doe, The Legal Framework of the Church of England: A Critical Study in a Comparative Context (Oxford: Clarendon Press, 1996).

7 See Norman Doe, "Ecclesiastical Quasi-Legislation," in Norman Doe, Mark Hill, and Robert Ombres, eds., English Canon Law (Cardiff: University of Wales Press, 20__, 93-103.

8 See church-state models in Norman Doe, Law and Religion in Europe: A Comparative Introduction (Oxford: Oxford University Press, 2011); Norman Doe, "The Concordat Concept as Constitutional Convention in Church-State Relations in the United Kingdom," in Puza and Doe, ed., Religion and Law in Dialogue, 237-50. 
Mark Hill's masterful Ecclesiastical Law, 9 has done more to help the Anglican Church get its legal house in full order.

Professor Doe has continued to write on discrete topics of Anglican church law since publication of this masterwork - issues of marriage and sexuality, 10 clerical ordination and discipline, 11 and a forthcoming book on the specialized church laws governing those glorious Anglican cathedrals that still attract tourists and BBC viewers by the millions, albeit rather too few local parishioners today. 12 He has also applied his immense learning directly to Anglican Church law reforms, serving on the Legal Advisory Committee of the Church of England, as a consultant to the Primates of the Anglican Communion, a member of the Lambeth Commission, and a chancellor of the Church of England in his own right. He has also sponsored ongoing conversations on important church questions with timely speeches and articles for the Ecclesiastical Law Society and its flagship journal, the Ecclesiastical Law Journal, on whose editorial board he has long sat.

An exemplary product of his church leadership was his clarion call for principled reform and covenantal unity of the 44 autonomous provinces of the worldwide Anglican communion set out in his book, An Anglican Covenant: Theological and Legal Considerations for a Global Debate (2008). 13 Like every church, the Anglican Church has always faced dissent and debate over fundamentals of the faith, including in recent years, deep angst over women's ordination and changes to the Book of Common Prayer. But the schisms that have emerged over homosexuality - whether gays, lesbians, bisexuals, and transsexuals should be admitted to baptism, communion, marriage, ordination, episcopal succession - have rent worldwide Anglican asunder, with sharp schisms emerging between and among English, African, and North American Anglican churches. Professor Doe uses the venerable biblical principle of "covenant" (foedus in Latin) to call the church back to its via media. The idea of "covenant" captures the heart of a Christian communion in word and sacrament that holds worldwide Anglicans together. It underscores the biblical reality that a "covenanted people" must be mutually sacrificial and accountable to each other and God, and will be "blessed and cursed" accordingly. It underscores the biblical reality that God remains faithful and forgiving to his covenanted people, even when they depart radically from his law and word. Anglicans of the world can take a hearty lesson from this biblical trope, Doe argues.14 Moreover, the Latin term for "covenant," foedus, is the root of the term

9 3d ed. (Oxford: Oxford University Press, 2011).

10 Norman Doe, ed., Marriage in Anglican and Roman Catholic Canon Law (Cardiff: The Centre for Law and Religion, 2009).

11 James Conn, Norman Doe, and Joseph Fox, eds., Initiation, Membership, and Authority in Anglican and Roman Catholic Canon Law (Cardiff: The Centre for Law and Religion: Rome: Ponitifical Gregorian University and Pontifical University of St. Thomas Aquinas, 2005); Norman Doe, ed., The Formation and Ordination of Clergy in Anglican and Roman Catholic Canon Law (Cardiff: The Centre for Law and Religion, 2009).

12 Norman Doe, The Legal Architecture of English Cathedrals (forthcoming)

13 (Norwich: Canterbury Press, 2008).

14 Ibid. See further John Witte, Jr., "The Covenant of Marriage: Its Biblical Roots, Historical Influence, and Modern Uses," INTAMS Review on Marriage and Spirituality 18 (2012): 147-165. 
"federalism" which has both political and ecclesiastical implications. Just as a group of semi-autonomous states or provinces can be united into a single national state with certain overarching and preemptory commitments and commands, so the 44 provinces of worldwide Anglicanism can remain united under the final authority of the Archbishop of Canterbury and its episcopal structures and preemptory norms. All the virtues of federalism are captured in this kind of "ecclesiastical federalism" - allowing local diversity and experimentation on the adiaphora of the faith without jeopardizing unity or membership. There is clever and cogent ecclesiology at work in Doe's formulations.

Having mastered the intricacies of the laws of the churches of Wales and England, Professor Doe gradually widened his scholarship to include Roman Catholic canon law, both in its own right, and in rich comparison with Anglican law. The millennium-old canon law system of the Catholic Church - culminating in the 1983 Code of Canon Law -- was a constant comparative touchstone for him in his earlier writings. 15 But in 2000, he began a series of writings on what he aptly called "comparative canon law" - analyzing concretely how Catholic and Anglican canon law systems deal with parallel issues of clerical ordination, support, and discipline, church baptism, initiation, and membership, marriage, divorce, and sexual morality, among many other topics. 16 Here, too, his work has been deliberately collaborative, through his leadership in the Colloquium of Anglican and Roman Catholic lawyers, and his editorship of several anthologies on comparative canon law topics as well as the journals Nomokonika and Annuario di Diritto Comparato delle Religioni.

Driving this long study of (comparative) canon law has been Doe's quiet insistence that church law is an important but too often neglected foundation for principled Christian ecumenism. For all the historical and theological differences that have and still divide Christian traditions and denominations, Doe argues, the Christian church universal has always been united in its devotion to and need for church law. From the earliest instructions of St. Paul or the Didache until today, the Christian church has been structured as a legal entity that depends on rules, regulations, and procedures to maintain its order, organization, and orthodoxy. Still today, the most loosely formed single congregation and the most massive Catholic, Protestant, or Orthodox denomination, has law as its backbone, balancing its spiritual and structural dimensions, and keeping it straight and strong especially in times of crisis. Some church laws are written, others are customary. Some are codified, others more loosely promulgated. Some are mandatory, others probative or facilitative. Some are universal canons, others are local and variant. Some are biblically-based, some products of reason, tradition and experience. Some deal with the dogmatic essentials of the faiths, others with the discretionary adiaphora. Some are internally created by the church's own government, others are externally imposed by the state. Some rules are declared by ecclesiastical hierarchies, others are democratically selected. But, for all this variety, church law is a common and necessary feature of church life, and an essential dimension of ecclesiology and theology.

15 See esp. Doe, The Legal Framework.

16 See sources in notes 6 and 10-11 above. 
It is this latter insight that inspired Professor Doe's latest masterwork on Christian Law (2013). 17 Here, for the first time, we find a comprehensive comparison of the church laws operating in all the largest Christian denominations in the world - Catholic, Orthodox, Anglican, Lutheran, Methodist, Reformed, Presbyterian, Congregational, United, and Baptist. The tight topical and analytical grids of his earlier work on the church laws of Wales and England, and of Anglicanism and Catholicism, are now laid atop all these forms and norms of ecclesiastical discipline and regulation. What he discovers is that common laws and regulations hold the worldwide church together much like the ancient confessions and creeds still do. "Though dogmas may divide," he writes, "laws link Christians across traditions" and around the world today. Indeed, "all denominations of the faith share common principles in spite of their doctrinal divisions."18 Here we have not only a powerful example of the "confluence of law and religion" - this book's main topic and title -- but also a strong foundation on which to build a global principled ecumenism.

Professor Doe is now preparing to take the next natural steps in this comparative law pilgrimage - namely, analyzing the operation of religious legal systems altogether, especially in Western liberal democracies. Anglican Archbishop Rowan Williams gave this topic a new urgency with his (in)famous comment that some accommodation of Islamic law was "unavoidable" in the United Kingdom.19 What this exposed, to the surprise of many, was the reality that not only Christian churches, but Jewish, Islamic, and other religious and cultural groups had been using their own internal legal systems to govern large portions of the lives of their voluntary faithful. Joining an ample cue of others who have weighed in for comment, Professor Doe and his colleagues wrote several trenchant pieces on the important and necessary role of religious tribunals in modern democracies. 20 They also warned that failure to accommodate Islamic tribunals, albeit with tight regulations and supervision, would soon jeopardize Christian canon law, too. They call instead for religious autonomy over core matters of the faith and voluntary faith community, and shared jurisdiction over the classic res mixta - marriage and family life, charity and social welfare, education and schooling, and others areas of life that feature spiritual and temporal dimensions .21

This points to an important distinction that Professor Doe has drawn between "religious law" (the aforesaid internal laws governing the church and other religious bodies) and "religion law" (the law of the state and international community that has to do with religion). Religion law, he writes, "may be considered analogous to family law:

17 Norman Doe, Christian Law: Contemporary Principles (Cambridge: Cambridge University Press, 2013).

18 Ibid., 1-10, 384-387 and dust jacket.

19 See Robin Griffith-Jones, ed., Islam and English Law: Rights, Responsibilities and the Place of Shari'a (Cambridge: Cambridge University Press, 2013).

20 See, e.g., G. Douglas, et al, "Religious Divorce in England and Wales: Religious Tribunals in Action," In P. Shah et al, eds., Family, Religion, and Law: Cultural Encounters in Europe (Farnham: Ashgate, 2014), 195-208; R. Sandberg, et al., "Britain's Religious Tribunals: 'Joint Governance' in Practice," Oxford Journal of Legal Studies 33 (2013): 263-291.

21 Norman Doe, Comparative Religious Law: Judaism, Christianity, and Islam (forthcoming); Doe, Law and Religion in Europe. 
rather than corresponding to a certain legal action, like tort law, it relates to an entity that has meaning outside the legal domain, is impacted by a number of different areas of law, is seen largely as a 'problem' to be tackled and has a goal, the achievement of which is increasingly seen as a universal human right."22 His Law and Religion in Europe book is a crisp and clear overview of this two-track system legal system as it operates in Western Europe. Religion law includes not only the classic individual and group religious freedom norms set out in national statutes (like the 1998 Human Rights Act in England), regional instruments (like Article 9 of the European Convention on Human Rights), or the international human rights documents (like Article 18 of the International Covenant on Civil and Political Rights). It also covers the intricate rules and regulations governing corporate religious life (religious property, polity, registration, labor, workplace, contracts, finance, taxation, exemption, discipline, governance, land use, historic preservation, zoning, and more); and private religious life (freedom of conscience, religious equality and non-discrimination, freedom of worship, assembly, association, publication, interaction, parenting, travel, and more); and the aforesaid res mixta (education, social welfare, and family and the individual rights and institutional structures that attend them). The "religious laws" from within, and the "religion laws" from without, together help shape the individual and corporate life of religions. The inevitable tension points between these internal and external laws governing religion are worked out in regulatory exemptions, statutory accommodations, national or regional concordats and covenants, and sometimes monumental cases before constitutional courts or human rights tribunals. 23

\section{The Broader Field of Law and Religion Today}

The main themes of Professor Doe's rich scholarship are illustrative of the broader field of law and religion study today. As other chapters in this volume document, the global guild of law and religion scholarship has grown rapidly in recent years, with thousands of scholars now at work on all continents, and with scores of journals, blogs, and other social media holding this global field together, together with an impressive number of books.

First, by far the largest body of law and religion scholarship is devoted to issues of religious freedom in American, European, and international contexts, and this topic will continue to dominate scholarship in the foreseeable future.24 Though the religious freedom case law of individual courts, especially the United States Supreme Court and the European Court of Human Rights, get most of the attention, a growing number of scholars are following Professor Doe's comparative law methodology. This new scholarly emphasis is part and product of the rise of comparative legal studies

22 Doe and Sandberg, eds., Law and Religion, 11-12.

23 Doe, Law and Religion in Europe; see also Puza and Doe, eds., Religion and Law in Dialogue; Mark Hill, Norman Doe, and Russell Sandberg, Religion and Law in the United Kingdom (Alphen aan den Rijn: Kluwer Publications, 2011).

24 See, e.g., Kent Greenawalt, Religion and Fairness, 2 vols. (Princeton, 2006-2008); Michael W. McConnell, John H. Garvey, Thomas C. Berg, Religion and the Constitution, 2d ed. (New York, 2006); Douglas Laycock, Religious Liberty, 5 vols. (Grand Rapids, MI, 2010- ). 
altogether around the world, as well as by new interest in the constitutional transformations of post-colonial Africa, post-fascist Latin America, and post-Communist Russia, Eastern Europe, and central Asia. It is also driven, in part, by the new great awakening of religion around the world that has radically shifted the religious demographic landscape of the West, and transformed the Global South. 25

Second, Professor Doe's main focus on comparative church law is part and product of growing wave of general scholarly work of the internal religious legal systems of the great world religions. Each of these world religions - especially Christians, Jews, and Muslims --- have long had their own internal legal specialists. But these topics are now becoming more mainstream in law, religion, sociology, history, and anthropology departments of research universities and societies worldwide. Cambridge University Press, for example, has inaugurated a series of fresh studies on law and Christianity, Judaism, Islam, Hinduism, Buddhism, Confucianism, and Indigenous Religions. 26 Other books are beginning to emerge offering intra- and interreligious perspectives on discrete legal topics - human rights, family law, constitutionalism, private law, and more. 27 Norman Doe-type comparativists are now at work in every one of the world religions.

Third, a small library of books has also emerged from this international guild documenting the contributions of the world's religions and their religious legal systems to the secular legal systems around them, both historically and currently. Part of this inquiry concerns the exportation, transplantation, or accommodation of discrete internal religious rules or procedures into secular legal systems. But more of this inquiry concerns the influence of religious ideas and practices on the complex doctrines of public, private, penal, and procedural law of the state. In the Western tradition, numerous historians have documented the successive influences of Christianity on Roman law, Germanic law, medieval and early modern canon law, civil law, and the common law, and the eventual colonization of these efforts throughout the world. Similar work is now being done on the cross-cultural legal influences of the laws of Judaism, Hinduism, and Confucianism, and especially the tremendous influence of Islamic law on the secular laws of the 55 Muslim-majority states today and their political predecessors.

25 See a good summary and sampling of the recent literature and instruments in W. Cole Durham, Jr. and Brett G. Scharffs, Law and Religion: International, National, and Comparative Perspectives (New York, 2010); Johannes A. van der Ven, Human Rights or Religious Rules? (Leiden, 2010); Natan Lerner, Religion, Secular Beliefs and Human Rights: 25 Years After the Human Rights Declaration (Leiden, 2006); Tore Lindholm, W. Cole Durham, Jr., and Bahia G. Tahzib-Lie. Facilitating Freedom of Religion or Belief: A Deskbook (Leiden, 2004).

26 See John Witte, Jr. and Frank S. Alexander, eds. Christianity and Law: An Introduction (Cambridge: Cambridge University Press, 2008); id., Christianity and Human Rights: An Introduction (Cambridge, 2011); Timothy Lubin, Donald R. Davis, and Jayanth K. Krishnan, eds., Hinduism and Law: An Introduction (Cambridge, 2010); Christine Hayes, ed., Judaism and Law: An Introduction (Cambridge, forthcoming); Rebecca French et al., eds., Buddhism and Law: An Introduction (Cambridge: Cambridge University Press, 2015). See also, e.g., Michael W. McConnell, Robert F. Cochran, and Angela Carmella, eds., Christian Perspectives on Legal Thought (New Haven, CT: Yale University Press, 2001).

27 See, e.g., Kristine Kalanges, Religious Liberty in Western and Islamic Law: Toward a World Legal Tradition (Oxford University Press, 2012); Don S. Browning, et al., eds., Sex, Marriage, and Family in World Religions (New York: Columbia University Press, 2006). 
Fourth, a whole new industry of law and religion scholarship has emerged on religious sources and dimensions of discrete legal topics, like human rights and religious freedom. A central question animating this literature is whether human rights are a universal good of human nature or a distinctly Western (Christian) invention that has no easy resonance in other cultures with different founding beliefs and values. If human rights are truly universal, what other formulations besides those rooted in Western philosophy, theology, and culture need to be incorporated? If human rights are distinctly Western (Christian) inventions, what other normative structures and systems do non-Western traditions offer to protect human dignity and to promote peace, justice, and an orderly society? A related question is whether human rights norms must now be cast in secular or neutral language in order to be legitimate and universal. Are Christian, Jewish, Islamic, Hindu, Buddhist, Confucian, Indigenous and other such declarations of human rights now in vogue, by definition, parochial and exclusive?28 Another small library of books has emerged analyzing the wide range of human rights issues that confront religious persons and communities today. A central question at work in this literature is whether freedom of religion and belief is something distinctive or simply the sum of all the other rights that other parties can claim, too. If religious freedom is distinctive, what special rights and liberties attach uniquely to religious parties that are not given to other non-religious parties? If religious freedom is not distinctive, how do core claims of conscience or central commandments of faith get protected when they run contrary to the cultural mainstream or majoritarian rules? 29

Fifth, another body of literature has grown around the perennially contested issues of law, religion, and family life. Three new questions are now attracting a great deal of new scholarly attention. The first concerns the growing contests between religious liberty and sexual liberty. May a state require a minister to marry a gay or interreligious couple, a medical doctor to perform an elective abortion or assistedreproductive procedure, or a pharmacist to fill a contraceptive prescription -- when those required actions run counter to those parties' core claims of conscience or central commandments of their faith? May a religious organization dismiss or discipline an official or member because of their sexual orientation or practice, or because they had a divorce or abortion? These are becoming major points of contestation and litigation. 30 A second question concerns religiously-based polygamy. For nearly two millennia, the West has rejected polygamy, calling it a capital offense from the ninth to the nineteenth century. These issues are back, with various Muslims, Fundamentalist Mormons, and Traditional religions and cultures pressing their case for toleration if not recognition of polygamy on grounds of religious freedom, sexual autonomy, domestic privacy, and

28 For a recent summary of this literature, with ample bibliography, see John Witte, Jr. and M. Christian Green, eds., Religion and Human Rights: An Introduction (Oxford, 2011).

29 See John Witte, Jr. and Joel A. Nichols, Religion and the American Constitutional Experiment, $4^{\text {th }}$ ed. (Oxford: Oxford University Press, 2016); Kathleen Brady, The Distinctiveness of Religion in American Law (Cambridge: Cambridge University Press, 2015).

30 See, e.g. Robert K. Vischer, Conscience and the Common Good: Reclaiming the Space Between the Individual and the State (Cambridge: Cambridge University Press, 2010); Kent Greenawalt, Private Consciences and Public Reasons (New York, 1995). 
equal protection. This, too, has triggered a small avalanche of writing. $31 \mathrm{~A}$ third question concerns the growing call by selected Muslims, and other religious minorities to opt out of the state's family law system and into their own religious legal systems. This is raising a lot of hard legal and cultural questions: What forms of marriage should citizens be able to choose, and what forums of religious marriage law should state governments be required to respect? How should religious minorities with distinct family norms and cultural practices be accommodated in a society dedicated to religious liberty and self-determination, and to religious equality and non-discrimination? Is legal or normative pluralism necessary to protect Muslims and other religious believers who are conscientiously opposed to the values that inform modern state laws on sex, marriage, and family? Doesn't state accommodation or implementation of a faith-based family law system run the risk of higher gender discrimination, child abuse, coerced marriage, unchecked patriarchy, or worse, and how can these social tragedies be avoided? Won't the addition of a religious legal system encourage more forum shopping and legal manipulation by crafty litigants involved in domestic disputes, often pitting religious and state norms of family against each other? Does the very state recognition, accommodation, or implementation of a religious legal system erode the authority and compromise the integrity of those religious norms? Isn't strict separation of religious norms and state laws the best way to deal with the intimate questions of sex, marriage and family life? These hard questions are generating a great deal of important new scholarship.32 Comparable complex work can be found on the law and religion issues surrounding education, charity, poor relief, immigration, environmental care, sex trafficking, warfare, torture, terrorism, and more.33 Almost every major cultural topic now is being viewed, in part, through the binocular of law and religion.

Sixth, natural law theory is becoming a topic of growing interest again, having once dominated patristic, medieval, and early modern Catholic, Protestant, and Enlightenment thought before giving way to modern legal positivism. The renaissance of natural law theory began already in the mid-twentieth century. The horrible excesses of Nazi Germany and Stalinist Russia catalyzed the modern international human rights revolution, which defined and defended the natural rights protections of human dignity and the natural law limits on state power. The rise of Catholic social teachings and the monumental reforms of the Second Vatican Council in 1962-1965 together gave further powerful impetus to Catholic natural law theories. A number of Jewish, Protestant, Eastern Orthodox, and Muslim scholars are now also resurrecting the rich natural law teachings of their own traditions, and developing new natural law theories to address fundamental legal questions today in and on terms that others with different faith

31 See John Witte, Jr., The Western Case for Monogamy over Polygamy (Cambridge: Cambridge University Press, 2015).

32 See, e.g., Joel A. Nichols, ed., Marriage and Divorce in a Multicultural Context: Multi-Tiered Marriage and the Boundaries of Civil Law and Religion (Cambridge, 2012); Rex Ahdar and Nicholas Aroney, eds., Sharia in the West (Oxford, 2010); Gopika Solanki, Adjudication in Religious Family Laws: Cultural Accommodation, Legal Pluralism, and Gender Equality in India (Cambridge: Cambridge University Press, 2011).

33 See, e.g., Kerry O'Halloran, Religion, Charity, and Human Rights (Cambridge: Cambridge University Press, 2014) and a good sampling of essays in Silvio Ferrari and Rinaldo Cristofori, eds., Library of Essays on Law and Religion, 4 vols. (Farnham: Ashgate, 2013). 
traditions can appreciate. 34 And all these groups have found interesting overlaps with the burgeoning religion and science scholarship that is exposing the natural foundations of human morality and sociability. 35 Natural law theory, while still controversial, is becoming a promising new arena of interreligious and interdisciplinary dialogue.

Seventh, natural law arguments often inform a related area of continued importance in law and religion study: the topic of legal ethics, both by itself and in comparison with theological ethics, business ethics, medical ethics, and more. Legal and theological ethicists have long recognized the overlaps in form and function of the legal and religious professions. Both professions require extensive doctrinal training and maintain stringent admissions policies. Both have developed codes of professional ethics and internal structures of authority to enforce them. Both seek to promote cooperation, collegiality, and esprit de corps. There are close affinities between the mediation of the lawyer and the intercession of the cleric, between the adjudication of the court and the arbitration of the consistory, between the beneficence of the bar and the benevolence of the diaconate. Ideally, both professions serve and minister to society. Both professions seek to exemplify the ideals of calling and community. Nonetheless, there can be strong tensions between one's legal professional duties and personal faith convictions as well. What does it mean to be a Christian, Jewish, Muslim, Hindu, or Buddhist lawyer at work in a secular legal system? These topics now have attracted a small cluster of important new scholarship. 36

Eighth, this last question -- about the place of the religious believer in the legal profession - has raised the broader question of the place of overt religious arguments in legal discourse altogether. This is in part an epistemological question: whether legal and political argumentation can and should forgo religious and other comprehensive doctrines in the name of rationality and neutrality. In America, this is also in part a constitutional question: whether the First Amendment prohibition on establishment of religion requires that all laws be based on secular and neutral rationales in order to pass constitutional muster. In the heyday of secular liberalism and strict separationism in the 1960s and 1970s, it was common to insist that all political debates sound in terms of rationality and neutrality. 37 Today, a number of scholars have argued that religious and

34 See, e.g., David Novak, Anver M. Emen, and Matthew Levering, Natural Law: A Jewish, Christian, and Islamic Trialogue (Oxford: Oxford University Press, 2014); David VanDrunen, Natural Law and the Two Kingdoms: A Study in the Development of Reformed Social Thought (Grand Rapids, MI, 2010); John A. McGuckin, The Ascent of Christian Law: Patristic and Byzantine Reformulations (New York, 2011); John Finnis, The Collected Essays of John Finnis, 5 vols. (Oxford: Oxford University Press, 2012).

35 See, e.g., Michael Welker and Gregor Etzelmüller, eds., Concepts of Law in the Sciences, Legal Studies, and Theology (Tübingen: Mohr Siebeck, 2013).

36 See, e.g., Symposium, "The Relevance of Religion to a Lawyer's Work: An Interfaith Conference," Fordham Law Review 56 (1998): 1075-1651.

37 See, e.g., John Perry, The Pretenses of Loyalty: Locke, Liberal Theory, and the American Political Theology (Oxford: Oxford University Press, 2010); Steven D. Smith, The Disenchantment of Secular Discourse (Cambridge, MA: Harvard University Press, 2010); Paul Horwitz, The Agnostic Age: Law, Religion, and the Constitution (Oxford: Oxford University Press, 2011); Sarah Barringer Gordon, The Spirit of the Law: Religious Voices and the Constitution in Modern America (Cambridge, MA: Belknap University Press, 2007). 
other comprehensive doctrines are essential parts of an enduring legal and political morality. 38

Finally, questions of law and religious language, have also raised broader questions about the overlaps between legal and theological interpretation, translation, and hermeneutics. Legal historians have long been intrigued by the overlaps between the scholarly methods used to interpret the Bible and the constitution, a code and a creed, a consistory judgment and a judicial opinion. The rise of modern literary theory and of form-critical methods of biblical interpretation has heightened this scholarly interest in how to discern the original meaning and understanding of authoritative texts. And with the rise of globalization and the study of global law and world religions, a number of jurists have become keenly interested in the questions of translation, transplantation, and transmutation of legal and religious ideas across cultural, disciplinary, and denominational boundaries. 39

38 See, e.g., Michael J. Perry, Under God? Religious Faith and Liberal Democracy (Cambridge: Cambridge University Press, 2003); id., The Political Morality of Liberal Democracy (Cambridge: Cambridge University Press, 2010).

39 See, e.g., Kent Greenawalt, Legal Interpretation: Perspectives from Other Disciplines and Private Texts (Oxford: Oxford University Press, 2010); Jaroslav Pelikan, Interpreting the Bible and the Constitution (New Haven, CT: Yale University Press, 2004); Milner S. Ball, The Word and the Law (Chicago: University of Chicago Press, 1993). 